Fluctuating Alliances 


\section{Contact Zones}

\section{Editors}

Lars Blunck, Bénédicte Savoy, Avinoam Shalem

\section{Volume 6}




\section{Fluctuating Alliances}

Art, Politics, and Diplomacy in the Modern Era

Editor

Pilar Diez del Corral Corredoira

\section{DE GRUYTER}


This publication was generously supported by a Ramón y Cajal project (2017-22131)

"Academias artísticas, diplomacia e identidad de España y Portugal en la Roma de la primera mitad del siglo XVIII" funded by the FSE/Agencia Estatal de Investigación (Spain). It has also received support by the department of Kunstgeschichte der Moderne at the Technische Universität (Berlin).
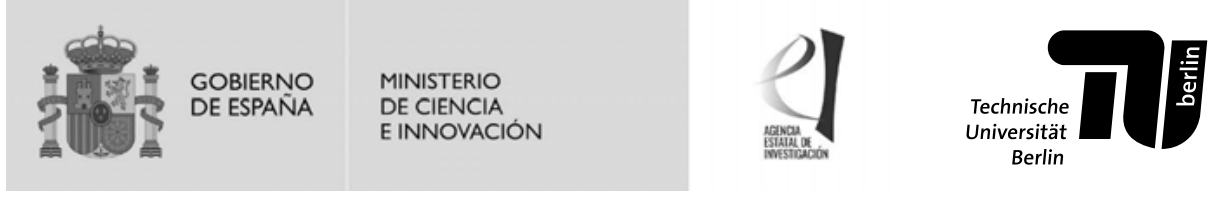

ISBN 978-3-11-060489-4

e-ISBN (PDF) 978-3-11-060641-6

ISSN 2196-3746

Library of Congress Control Number: 2021935536

Bibliographic information published by the Deutsche Nationalbibliothek

The Deutsche Nationalbibliothek lists this publication in the Deutsche Nationalbibliografie;

detailed bibliographic data are available on the Internet at http://dnb.dnb.de.

(C) 2021 Walter de Gruyter GmbH, Berlin/Boston

Cover illustration: Medal commemorating the Treaty of Rastatt and Baden, designed and produced in Nuremberg. Silver. Kunsthistorisches Museum Vienna, Numismatic Collection, MK 1365bb.

KHM-Museumsverband

Typesetting: Satzstudio Borngräber, Dessau Roßlau

Printing and binding: Beltz Bad Langensalza GmbH, Bad Langensalza

www.degruyter.com 